\title{
A department under siege: How Philosophy at Stellenbosch was split in order to survive
}

\author{
Van Niekerk, Anton A \\ Stellenbosch University \\ aavn@sun.ac.za
}

\begin{abstract}
This article discusses the extraordinary history of the teaching of philosophy at Stellenbosch University, with a particular focus on the events that led to the split of the department in 1967, and its later reunification in the late 1980's. The tensions that characterised these events, ultimately leading to the split of the department, were informed by resistance on the part of the Dutch Reformed Church (DRC) clergy, embodied by the supervisory body ('kuratorium') presiding over what would later become the faculty of theology of the Stellenbosch University, to the seemingly unorthodox and controversial interpretations of religious doctrine by a lecturer within the department of philosophy, Dr JJ Degenaar. The eventual solution to these differences was the initial creation of two 'streams' in the department of philosophy, one of which would be political philosophy taught by Degenaar, and ultimately the creation of a separate department of political philosophy, headed by Degenaar. The article also deals with the process of re-unification of the two departments in the late 1980's. Several insights can be gleaned from an analysis of these events. Firstly, they reveal the extent to which the DRC curatory was able to influence academic affairs at that time, as well as to the extent to which Stellenbosch University allowed its institutional autonomy to be compromised. Secondly, they show how a certain model of religious experience and faith that was quite prominent in DRC circles in the late nineteenth century, was systematically overtaken by another model in the course of the early twentieth century. Finally, they show that within the two departments, a healthy culture of not only respect and collegiality, but also continued philosophical and political debate, was maintained throughout the 20 years of formal (30 years of effective) separation, thus illustrating the value of dialogue over intellectual immobility.
\end{abstract}

Key words

Philosophy; Stellenbosch University; curatory of the Kweekskool; im/mortality of the soul; Johan Degenaar; JF (Freddie) Kirsten 


\section{The origins of philosophy teaching at Stellenbosch}

Philosophy at Stellenbosch University dates back to the origin of the town's higher educational tradition with the creation, on 1 November 1859, of the 'Teologiese Kweekskool', a seminary for the training of ministers for the Dutch Reformed Church. This training institution for DRC clergy was established as a bulwark for the defence and sustenance of orthodox Christian theology in response to the influence, effects and ramifications of the so-called 'liberal movement' of the mid-nineteenth century in South Africa - a movement associated with individuals like DP Faure, JJ Kotze, SP Heyns, HV Leibrandt and TF Burgers (Rossouw 2000; Brümmer 2013), minister of the Hanover Congregation, who eventually became president of the Zuid-Afrikaanse Republic. Philosophy was taught by the first professors of the Kweekskool, John Murray and NJ Hofmeyr, from the outset. In 1877, Johannes Isak Marais was also appointed as professor in the Kweekskool in order to teach the 'philosophical subjects' i.e. 'natural theology and speculative and practical philosophy' (Brümmer 2013: xi).

In 1866, a secondary school known as the Stellenbosch Gymnasium, now known as Paul Roos Gymnasium, was created with the express purpose of assistance in the preparation of potential students of the Kweekskool. This was reinforced by the addition of a post-matric year, and eventually two further years of preparatory undergraduate studies, in what was first named the 'Stellenbosch College' and eventually the 'Victoria College' an institution that was, for many years, not clearly distinguished from the school. In this context, Prof. Thomas Walker was, in 1878, appointed to teach both English and philosophy. From 1904, he focused exclusively on philosophy. Walker was joined in 1911 by Prof. NJ Brümmer, who was the first full-time professor of philosophy.

It can therefore be claimed that 1911 formally represents the year of birth of the department of philosophy, as a department distinct from English at Stellenbosch. Brümmer, an ex-clergyman of the DRC, took his main responsibility to be the philosophical orientation of students preparing for study at the Kweekskool in order to become DRC clergy. Brümmer, although a highly admired and influential figure in his time, did not write much and was philosophically mainly influenced by the late nineteenth century tradition of neo-idealism as represented in the work of figures such 
as JE Turner and J Leighton (Kirsten 1972). It is a tradition that saw an almost complete demise in the twentieth century. In the controversial $\mathrm{Du}$ Plessis heresy trial of the early 1930's (See Nash 2009: 65-84, as well as Rossouw 2000), Brümmer was known to be an outspoken supporter of $\mathrm{Du}$ Plessis (Brümmer 2013: xi).

\section{Degenaar comes to Stellenbosch}

Not only does education in philosophy therefore have a long tradition at Stellenbosch (see Nash 1997); it can also claim to have one of the most poignant and complex histories of any part of this institution. The main reason for this is the highly unusual story of the controversy surrounding Dr JJ Degenaar, senior lecturer in philosophy from 1949, which led to the splitting of the department into two in 1967. This year (1967) saw the formalisation of this process, which was indeed preceded by a memorable train of events dating back to 1958. In this drama, the four central actors were the then rector, Prof. HB Thom, the head of the department of philosophy, Prof. JF Kirsten, the senior lecturer officiating at the time, Dr. JJ Degenaar, and the Dutch Reformed Church, embodied by the 'kuratorium' or supervisory curatory presiding over the Kweekskool, which during the 1950's was still the Theological Seminary at Stellenbosch, and only in 1962, became the full-fledged faculty of theology of the Stellenbosch University. The record shows curatory members JS Gericke and JD (Koot) Vorster to be particularly prominent in developments. This article will henceforth be focused on no more than the outline of this extraordinary history. I shall briefly outline events and make a few interpretive comments at the end.

JF Kirsten was a student at Stellenbosch in the early 1930's at the height of the Du Plessis controversy. He concurred with his philosophy professor, Brümmer's, support of Du Plessis. This generated the wrath of (at least) one of his senior co-students, JD (Koot) Vorster, who, with others, objected to Kirsten's legitimation as minister of the DRC on completion of his theological training in 1934 . He was nevertheless admitted to the ministry by a majority vote of the curatory, and accepted a call to Kirkwood, where he ministered the congregation until 1942 when Brümmer (as was the custom in those days) solicited him and submitted his name as his (Brümmer's) successor (personal information from Prof. Kirsten and Rossouw). 
The post-Second World War period brought about significant changes in the intellectual climate at South African universities, particularly Stellenbosch. This contributed to a new surge of interest, no longer in the philosophical positioning of orthodox Christian belief, but in problems and approaches that dominated the intellectual life of a new generation of thinkers in the European context. Particularly prominent were phenomenology, existentialism and analytical philosophy. In the period between 1942 and 1950, Daantjie Oosthuizen, James Oglethorpe and Johan Degenaar proved themselves as the brightest lights of this new generation of philosophy students. Of the three, Degenaar was the only one who did not complete his theological studies and who kept a comparatively low profile in student politics. Yet it was he who was chosen by Kirsten to take up the new position of senior lecturer created in 1948, a position that had been temporarily filled by GS (Tappies) Möller for a few years before this. According to André du Toit, Degenaar was regarded as the 'safest' of the three in terms of continuing the traditional line of philosophy at Stellenbosch (Du Toit 2015). That idea turned out to be gravely mistaken.

\section{A new voice in the 1950 's}

The content of Degenaar's courses in the 1950's and the way in which his thinking contributed to a transformation of the tradition of philosophical reflection and teaching cannot be explored in this paper. Andrew Nash has written a comprehensive book dealing with those issues (Nash 2009: 65-130). Suffice it to say that his teaching, while on the one hand unorthodox, innovative and inspiring, was, at the same time, experienced as upsetting, disconcerting and unsettling for a number of students doing the admissions degree before entering the Kweekskool. It is also quite likely that these students' concern was encouraged and even exacerbated by a number of Dutch Reformed clergy, inside and outside of the curatory, as the stories about Degenaar's classes and claims reached their ears. What these students found particularly unnerving, was the fact that Degenaar, in both the topics that he taught and in his personal disposition, seemingly moved within the paradigm of conventional Christianity in most of his courses, yet availed himself of interpretations of long-held beliefs that dramatically unsettled these conventional beliefs. The paradigmatic example of this tendency in Degenaar was his continuance, on the one hand, of Kirsten's 
practice of praying at the start of a lecture, yet, on the other hand, infusing those prayers with, for these students, perplexing contents, e.g. 'Lord, until now, we have learned that our task is to make Christians out of people. Help us, henceforth, to make people out of Christians'. Another prayer ran as follows: 'Thank you for philosophy that helps us to look closely at life. Liberate us from our imagined certainties. Protect us from seeking new certainties, and make us content with the daily bread that you send us from heaven'.

It is safe to say that Degenaar's ideas were not necessarily experienced as undermining or disconcerting by all theological students at the time. In 1954, Danie Malan, son of (at the time) prime minister DF Malan and a theological student at the Kweekskool, published a controversial article in Polumnia, the annual student publication of the Theological Seminary. The title was: 'Our idea of the soul and where it comes from' (Malan 1954). ${ }^{2}$ This article precipitated much concern in conservative theological and ecclesiastical circles at the time. Malan basically argues that the idea of the human person as consisting of two entities, body and soul, of which the first perishes after death while the latter survives in eternity, either in heaven or hell, is not at all a biblical idea but wholly a creation of the Greek philosopher Plato (Malan, 1954: 36). This 'unbiblical' idea was then allegedly introduced to Christianity by St Augustine, the Bishop of Hippo, round about the year 413 A.D. Malan ascribes St. Augustine's inability to see the shortcomings of his appropriation of Plato's idea into Christian doctrine to St Augustine's ignorance of Hebrew and his quite limited knowledge of Greek (Malan, 1954: 37). This false doctrine, argues Malan, was perpetuated in the work of John Calvin. Interestingly enough, Malan claims support for his (Malan's) idea from the famous Dutch systematic theologian of the late $19^{\text {th }}$ and early $20^{\text {th }}$ century, Herman Bavinck, who, according to Malan, emphatically denied the doctrine of the immortality of the soul since this doctrine never occurs in the Bible. What the Bible

1 The first of these prayers is folklore in Stellenbosch; just about all Degenaar's students know this prayer. The second prayer is my English translation of a transcription of one of Degenaar's prayers by Zenobia Lutz. Lutz, one of Degenaar's ex-students, also transcribed a number of his other prayers in classes of him that she attended. Prof. DJ (Daniel) Louw was so friendly to make a file of these transcriptions available to me.

2 My translation of Afrikaans: 'Ons idee van die siel en waar dit vandaan kom'. 
does claim, according to Malan, is not the idea of the immortality of the soul, but the resurrection of the body - the body then as representation of the whole of the human person (Malan, 1954: 39).

According to a personal communication that I received from Prof. Vincent Brümmer who, at that time, was a student in the Kweekskool, the ideas of this article were immediately associated with and ascribed to Degenaar's influence on the young Malan, even though the article contains no reference to Degenaar whatsoever. Malan was in 1954 registered for an MA in philosophy which he did simultaneously with his theological course, as was customary at the time. As will become clear in the following paragraphs, the ideas of Malan do have a notable resemblance to ideas propagated by Degenaar in the course of the 1950's and assembled into the book Die sterflikheid van die siel (The mortality of the soul) early in the 1960's. The commotion around Malan's article was a clear precursor of the more sustained controversy that Degenaar's ideas - innocuous as they might seem to a current-day reader - provoked at the time.

\section{The controversy escalates}

Slowly but surely, resistance against the unnerving or challenging teaching methods and the ideas of this unusual man (Degenaar) began to grow. It is likely that this resistance might also have been fuelled by already established clergy who did not like what they heard about Degenaar's work. Carel Anthonissen, one of the first year theological students in 1966 who still attended Degenaar's first year logic class, claims that the image of Degenaar as an almost 'devilish' underminer or subverter of faith was explicitly cultivated and reinforced by a few more senior students (Anthonissen, Undated: 1 ). ${ }^{3}$

3 In the unpublished article of Anthonissen he relates the fact that Degenaar was once, at a function, introduced by a very prominent senior student, Boy Geldenhuys (chair of the SRC and of the Afrikaanse Studentebond, as well as head student of Dagbreek residence), who saw fit to, in his speech, trace the etymological origins of Degenaar's surname in Dutch. The term 'degen', originally meant a 'dagger' ('dolk' in Afrikaans or Dutch). The suggestion was not even subtle: 'Degenaar' represents the idea of a sinister 'dagger', which is, on the one hand, always hidden from public sight, yet, on the other, razor sharp, dangerous - even deadly. Anthonissen writes: '...so dramatic and upsetting were the prejudices that in that time were held against Degenaar' (Anthonissen, Undated: 2, my translation) 
At the same time, a core of (usually the best performing) students were immensely impressed by how he taught them. They experienced Degenaar as a/the most powerful formative influence in their university education. ${ }^{4}$ An example of this is Jacques Kriel, an ex-student of Degenaar. In a personal communication, Kriel writes: 'I do not believe that Johan 'affected' the faith of any one of us. What we did attain, was a different perspective on and sensitivity for the [central message of] the gospel. We experienced him as a Christian, but we became strongly aware of his scepticism about and rejection of the standard theological models as well as the power structures operative in the church - although the latter was also executed with some sense of humour and never disrespectful. This we took over from him and tried to apply it' (Kriel 2016: 1). Anthonissen also mentions the fact that Degenaar, in those early years, was often noted as attending church services. His practice of praying in class and saying grace at home dinners continued for many years and is widely attested to.

The controversy surrounding Degenaar was, in particular, exacerbated by a number of critical papers that he delivered on the issue of faith in the idea of the 'immortality of the soul' - a collection that was eventually published as a book in 1963 by Simondium Publishers in Johannesburg, with the provocative title of Die sterflikheid van die siel (The mortality of the soul) (Degenaar 1963). In this book, Degenaar not only openly challenges the conventional Christian belief in an immortal soul that survives death, but introduces, for the time, radically new ideas about the meaning of human bodiliness or corporeality, insisting that the notion of the body encompasses the totality of our human identity and brings to expression in a much more imaginative way the significance of human existence. This doctrine obviously challenges and problematizes the (in church circles) conventional meanings of notions such as heaven, hell, punishment, purgatory, resurrection and eternal life. The body, for Degenaar, is the total or complete human being. He writes in this regard: 'Against the generally accepted belief I propose the model of the body as situation. This, however, leaves no space for a greater emphasis on one part of what it means to be a human being. It does acknowledge the significance of the idea of

4 For some of these testimonies, see the two Festschrifts offered to Degenaar at, respectively, his $60^{\text {th }}$ and $80^{\text {th }}$ birthdays, viz. Du Toit (ed) 1986 and Hertzog, Britz \& Henderson (eds) 2006. 
immortality, not because it literally suggests the fact of immortality, but because it [i.e. the claim to immortality] manifests something of man's attitude towards his body and towards death...I therefore want to propose that, rather than an immortal soul, [the idea of] a broken body opens the way to deepened insight into the expression "the image of God"' (Degenaar 1963: 82-84). ${ }^{5}$

This was a new, for that time highly unorthodox, and for conventional prospective theological students, disconcerting voice in the Philosophy Department, let alone for those who considered themselves the custodians of these students. Degenaar's performance was inevitably compared to that of Kirsten, and found to be profoundly different. Kirsten's successor, Hennie Rossouw, in a published tribute to Kirsten on the latter's retirement in 1973, wrote: 'Prof. Kirsten used his philosophical insights to clarify things that are unclear and to open rich perspectives, but never to burden young and vulnerable souls with problems - souls who could, as a result, be brought into and left in confusion' (Rossouw 1973). ${ }^{6}$ At the same time it must be stressed that there is no evidence at all of any tension between Kirsten and Degenaar at this or any other time. In all my research on this issue, as well as from personal information gleaned from the two individuals and their immediate colleagues, it is evident that their relationship remained mutually collegial, cordial and supportive.

\section{A settlement after the 'kuratorium' gets involved}

Two realities had nevertheless to be faced and dealt with in one way or another. The first was that the kuratorium of the DRC began to air complaints about Degenaar's allegedly subversive influence on some prospective theological students - subversive, it was claimed, to the point

5 My free translation. The original Afrikaans reads: 'Teenoor the gangbare opvatting stel ek die model van die liggaam as situasie. Dit laat egter geen ruimte vir 'n groter beklemtoning van een deel van die mens nie. Dit erken wel die betekenis van die onsterflikheidsidee, nie omdat dit op 'n egte onsterflikheid sou dui nie, maar omdat dit iets manifesteer van die mens se houding tot sy liggaam en tot die dood ... Ek wil dus voorstel dat, eerder as ' $n$ onsterflike siel, 'n gebroke liggaam die weg open tot 'n verdiepte insig in die uitdrukking 'die beeld van God'.

6 My free translation. The original Afrikaans reads: 'Prof. Kirsten het sy wysgerige inigte gebruik om onhelderhede op te klaar en ryke perspektiewe te open, maar nooit om probleme af te laai op onrype geeste wat daardeur in verwarring gebring kon word nie.' 
of causing people to lose their Christian faith. From an informal record in the archive of an undated meeting between the then rector, Prof. HB Thom (written in his handwriting), with Prof. Kirsten, Dr. Degenaar, Dr. GP van der Berg, Dr. JD Vorster (actuary of the Synod and member of the kuratorium) and Ds. JS Gericke (chair of the kuratorium), it is clear that these issues were discussed. Kirsten apparently went to great lengths to explain differences in philosophical approaches. Notably, these minutes state that, in terms of searching for a solution, 'Dr Degenaar is willing to co-operate, and even willing to be constrained ('om aan bande gelê te word') regarding the areas in which he will henceforth be teaching'. The second reality that became apparent towards the end of the 1950's and early 1960's was the fact that the Philosophy Department began to lose students. A document written by Kirsten that I will again refer to, shows the total numbers in the first four years (i.e. the three undergraduate years as well as the Honours year) dropping from 81 in 1953 to 49 in 1958 (Kirsten 1962) - a phenomenon generally acknowledged as one of the most damaging eventualities for the survival of a university department.

The question is, was there any solution to this grave problem facing the department whose discipline was contained in the very name of the faculty which it was part of, at the time? The minutes of the meeting of the Faculty of Letters and Philosophy ('Lettere en Wysbegeerte') of 7 May 1958 reveal the solution then conceived. Prof. Kirsten made a formal proposal that, starting in 1959, a new course in the alleged separate discipline of 'political philosophy' (Afrikaans 'staatsfilosofie') would be created as a second stream (the so-called B option). The A and B courses would have a common first year, but would differentiate from the second year onward. The differentiation would be maintained in the Honours course. While conventional contents (history of philosophy, as well as metaphysics, phenomenology and existentialism) would be maintained in the A option, which would be prescribed for prospective theological students and mainly offered by Kirsten (with a few remaining inputs by Degenaar), the B option, prescribed mainly for law students and others interested in politics, would entail a variety of themes from the tradition of political philosophy. ${ }^{7}$

7 From the official university documents referred to above, it seems clear that the split of philosophy into two 'streams' started in 1959. André du Toit, Degenaar's later direct colleague in the Political Philosophy Department, nevertheless claims that he was a 
Quite significantly, the minutes of this same Faculty Board Meeting (7 May 1958) contain an approved proposal that Senate be advised to investigate the possibility of creating a Department of Political Science 'into which the courses in political philosophy could be incorporated'.

It is clear that the creation of two 'streams' in the Philosophy Department represented a 'solution' that met with the approval of the kuratorium of the DRC. The archive contains a formal letter by Prof. Thom (dated 8 July 1958) addressed to Dr. JD (Koot) Vorster, actuary of the DRC Synod, in which this new arrangement is duly explained, the decisive role of Kirsten in conceptualising the new dispensation is acknowledged, and it is declared that both the Faculty Board and Senate have agreed to the new arrangement (Thom 1958a). This letter is answered by one from Dr Vorster (dated 10 July 1958) in which he articulates the satisfaction of the DRC in South Africa (the name of the Western Cape Synod of the DRC at the time) (Vorster 1958). In all my research, I could not find a single document containing the response of Degenaar himself to this train of events, except for the mentioned minutes of the initial meeting in which he, according to Thom, pledged his intended co-operation with the ruling.

It is notable that, in the interviews I had with Rossouw and Du Toit about their recollections of these events (both were out of the country at pivotal stages of developments), neither of them has a memory of any in-depth discussion of the matter with Degenaar himself. Degenaar was in many respects a remarkable man - the epitome of friendliness and politeness, someone who always encouraged conversation and paid minute attention to listening to people, thus encouraging them to acquire, articulate and argue for their own views, rather than having views imposed on them. $\mathrm{He}$ made a lasting impression on most people that he encountered - most of all his students. Although it is reasonable to assume that the events narrated

first year student in 1957, and that he was under the seemingly clear impression that the split already occurred in 1958. This is one of the many instances in doing this research where I was initially completely baffled by seemingly contradictory evidence as to that what actually happened! The probable explanation has to do with the fact that the two differentiated streams had a common first year, and that that first year in 1958 as well as the 1957 first year were recognised for both streams. Consequently, the new differentiated courses were then actually only offered from 1959 onwards, in accordance with the decisions reflected in the documents. 
above hurt him, he never admitted that much in any interaction that I am aware of.

From 1959 to 1962 the 'two stream' model was handled by Kirsten and Degenaar, as originally agreed. However, it became clear that their workload was too much; at that stage Kirsten was offering 19 and Degenaar 17 undergraduate and Honours classes per week. In the course of 1962 Kirsten consequently wrote a comprehensive motivation for the creation of a new post in the department (Kirsten 1962). What is also significant is that, in this motivating document, there is absolutely no reference to the ecclesiastical complaints against Degenaar that prompted the 1958 arrangement. The motivation for the two then existing streams in the department, is entirely developed along the lines of a renewed plea for the creation of a Department of Political Science for which the courses in the B option could be utilised. In his motivating document, Kirsten even mentions that the request for a political science department was originally voiced by the SRC in 1958! This creates the impression that Kirsten earmarked Degenaar to lead such a new department. It is also indicative of the fact that Kirsten at this stage deliberately downplayed the role of the earlier ecclesiastical complaints against Degenaar.

In the meantime (and in the same document: Kirsten 1962), Kirsten made an impressive and comprehensive argument that an ex-student of the department, HW Rossouw, would probably be available for appointment at the beginning of 1963, should the university agree to the creation of such a new post. It should be added that Kirsten discussed the situation with Rossouw for the first time on the former's visit to Europe in July of 1962. In this discussion Rossouw expressed his willingness to consider a possible appointment, but only on condition that Degenaar would be satisfied with the arrangement. After Kirsten's return to South Africa, Degenaar in a letter to Rossouw indicated his full support (Rossouw interview). Rossouw was awarded the doctorate in Theology at the Free University of Amsterdam on 3 May 1963 and in the meantime had been appointed senior lecturer in the Philosophy Department. He started working on 8 May 1963, and taught in both the A and B streams of the Philosophy Department until the end of 1968 (Rossouw interview). The Department of Political Philosophy officially came into existence from 1967, with Degenaar as head of department, and Rossouw then teaching in both departments. In the 
beginning of 1969 Degenaar was promoted to professor, while AB du Toit was appointed in a new post in the Department of Political Philosophy. Rossouw's involvement in the latter department then came to an end (Rossouw interview).

It is indeed a question as to what then happened to the idea of creating a Department of Political Science in which political philosophy (and possibly Degenaar in person) might play a prominent role. The record on this is not very clear. What is certain, is that such a department was created in 1966, but with Ben Vosloo (solicited from Unisa), and not Degenaar, as its head. In the mid-sixties it started to become clear that Degenaar was not only very critical of traditional Christian doctrine, but also of the policies of the apartheid state. Having, in a sense, been forced to focus on politics in his academic work (something he hardly ever did in the 1950's), he now gradually became a pronounced critic of apartheid - something that was not much appreciated in many circles of the Afrikaner-controlled state. Although I cannot (at this stage) prove it, it seems to me that Degenaar was consequently side-lined when the original suggestion of a Department of Political Science came to fruition.

\section{Re-unification in the 1980's}

What is left to discuss in this article, is the process that eventually led to the unification of the two departments in 1987. The number of students taking both philosophy and political philosophy as subjects started to show a notable rise in the seventies and eighties. Political Philosophy always had considerably less students than Philosophy. The pattern of prospective theological students constituting the bulk of the intake of the Philosophy Department, remained the case until well into the 1980's when the number of theological students dropped dramatically. At that stage, it had little effect on the Philosophy Department due to an overall shift in its clientele; non-theological students increasingly took philosophy as subject, and their numbers exploded in the course of the nineties - up to this very day, where an intake of 400 first years, 250 second years, 100 third years and 18 Honours students, with about 30 Masters and 15 doctoral students (the current - 2017 - figures) have become the norm. The student numbers of the Political Philosophy Department remained relatively small. These students were by and large quite intelligent law students. 
As the years progressed, a number of staff members were added to both departments. In 1969, André du Toit was appointed as senior lecturer in Political Philosophy. He was promoted to associate professor in the early 1980's, and, in 1986, left the department for an appointment as full professor in the Political Studies Department of UCT, from which he retired in 2003. Prof. Kirsten retired in 1973, after Hennie Rossouw was promoted to full professor in the Philosophy Department in 1972. Rossouw was, from 1 July 1974, joined by Prof WP (Willie) Esterhuyse, an ex-student of the department who, before his appointment at Stellenbosch, taught at the Universities of Durban-Westville and the (then) newly established Rand Afrikaans University (today the University of Johannesburg). Esterhuyse would, in the late eighties and early nineties, become a pivotal figure in facilitating start-up negotiations between the South African government and the ANC in exile. That, however, is a story outside the scope of this article. ${ }^{8}$ Rossouw and Esterhuyse alternated almost annually in chairing the department. An unfilled junior lectureship was used in the course of the 1970's to appoint temporary teaching assistance.

In 1980, Anton van Niekerk was appointed lecturer and Johan Hattingh junior lecturer in the Philosophy Department. The post of lecturer was newly created, mainly because of the rise in student numbers in the 1970's. Hattingh began working on 1 July 1980, and Van Niekerk, who had to do national service in 1980, could only start on 1 April 1981. Rossouw was eventually appointed as the University's first Vice-Rector for Academic Affairs from 1 January 1985. Van Niekerk was, from the same date, promoted to senior lecturer, and Hattingh to lecturer. Van Niekerk was eventually promoted to full professor from 1 July 1989, and Hattingh to full professor from 1 January 2003. In 1987, Willie van der Merwe was appointed as lecturer. He was eventually promoted to full professor in 1998, after Esterhuyse's retirement, and left the university and the country for an appointment in the Netherlands in the course of 2008. For its entire existence (1967 to 1987) the Political Philosophy Department never had

8 For this story, see WP Esterhuyse: End-game: secret talks and the end of apartheid. Cape Town: Tafelberg, 2012. This book was simultaneously published in Afrikaans with the title Eindstryd: geheime gesprekke en die einde van apartheid. As an indication of how pivotal Esterhuyse's role in bringing about these negotiations was generally regarded, a film based on this book was made in 2014 with William Hunt playing the role of Esterhuyse. 
more than two full-time staff, viz. Degenaar and Du Toit. For a number of years Andrew Nash assisted them with temporary lecturing, before he attained a full-time position at the University of the Western Cape, and later at the University of Cape Town.

The possibility of re-uniting the two departments was increasingly raised and discussed informally during the early 1980's. André du Toit, much more than Degenaar, played a prominent role in these exploratory conversations. As new staff joined the Philosophy Department (see previous paragraph) who had no first-hand experience of the events that led to the division of the two departments, the justification for the continuance of the split increasingly faded away. In addition, with the retirement and eventual demise of the authoritarian ecclesiastical figures that led the assault on Degenaar, together with a general relaxation of views as well as the liberalisation of ecclesiastical doctrine in the Dutch Reformed circles, it became more and more inexplicable and less justifiable to continue with the dispensation of two full-fledged Philosophy Departments - a phenomenon almost without precedent, not only in South Africa, but anywhere else in the world.

A further reason for the growing sentiment in favour of re-unification was the disposition of Degenaar himself. As already stated, he himself hardly pressed for re-unification. To do so, would create the impression that he felt seriously aggrieved by the events of 1958-1967, and anyone who knew Degenaar, understood that he would at all costs refrain from such selfbelittling behaviour (as he would regard it). At the same time, he had, on the face of it, increasingly lost interest in the intellectual issues that allegedly precipitated the split in the first instance - issues like the mortality of the soul, the non-metaphysical nature of God, Kierkegaard's existential idea of religious faith, and the like.

Because he was now chairing a department of Political Philosophy, he felt himself morally compelled to pay much more attention to issues in political philosophy. That precipitated a whole new chapter of controversy related to his ideas, teaching and public contributions. Degenaar now became one of the most astute and vociferous critics of South Arica's system of apartheid. Space will not allow me to explore the details of that role in this article; the interested reader is invited to peruse the discussions of his contributions in this regard in the different volumes of tribute to Degenaar that have 
been published. ${ }^{9}$ Suffice it to say that Degenaar never joined any opposition party or openly sympathised with liberation movements such as the ANC in exile. Although he often participated in public debate via the newspapers and other popular media, his main work was conceived and communicated in an academic context. He particularly relished the strategy of analysing the work of prominent Afrikaner intellectuals such as NP van Wyk Louw (according to many the most important Afrikaner poet and intellectual), Gerrit Viljoen (first rector of RAU and later a highly influential cabinet Minister in the 1980's) and Andries Treurnicht (leader of the right-wing opposition Conservative Party), identifying the inconsistencies in their work and pointing out the moral aberrations that followed from the application of their ideas.

Although Degenaar was loathed for these views by conservatives in the Afrikaner establishment of that time, this aspect of his work was welcomed and appreciated in the Philosophy Department, and increasingly at the University. There were differences in emphasis between Degenaar's and $\mathrm{Du}$ Toit's views, on the one hand, and views of people like Esterhuyse, Sampie Terreblanche (an economics professor at Stellenbosch) and others. Occasionally these differences gave rise to polemical public debates between Esterhuyse, Terreblanche and friends, nicknamed 'verligtes', on the one hand, and Degenaar, Du Toit and friends, nicknamed 'oorbeligtes'. In 1982, specifically, a spirited debate occurred in the letters column of the Afrikaans newspaper Die Burger about the central issue dividing 'verligtes' and 'oorbeligtes' - the question as to whether the best way for intellectuals to counter and end apartheid was to remain part of the establishment and promote change on the basis of 'loyal criticism' (the 'verligte' strategy) or to break openly with the apartheid system and express critique on the basis of officially and publicly declared opposition (the 'oorbeligte' strategy).

These debates, although interesting (even gripping) for young academics (like the author of this article at the time!) and parts of the public at large, were, in the end, not indicative of fundamental differences of purpose, but mainly about issues of the best means to attain the same end: the demise of apartheid. They certainly were not sufficient grounds for maintaining the existence of two full-fledged philosophy departments in the same

9 Cf. DuToit 1986 and Hertzog, Britz \& Hendserson (eds.) 2006. 
university. About the nature of the subject taught by both there was broad consensus.

There was an additional factor that considerably facilitated the unification of the two departments. This had to do with the shift in the clientele of the Philosophy Department in the course of the 1980's. Willie Esterhuyse, who mostly chaired the Philosophy Department during the 1980's (Van Niekerk acted as chair in 1985 and 1986 when Esterhuyse was on an extended sabbatical) increasingly came to the conviction that the positioning of the Philosophy Department as 'preparatory subject' for people on their way to theological studies, as mostly conceived by Brümmer and Kirsten, was no longer paramount. Although Philosophy was represented on the Faculty Board of Theology since the 1970's, it did not entail more formal links or a more secure and extended role of philosophy training in the theology curriculum. Philosophy was never strongly encouraged beyond the first year as a field that potential theologians should acquaint themselves with. Consequently Esterhuyse, who himself was more interested in sociopolitical philosophy and ethics, came to the conclusion that it would be better to position the Philosophy Department strategically as a centre of excellence in ethics; hence his own (at that stage in South Africa) ground-breaking work in the field of business ethics. This approach was enthusiastically embraced by Van Niekerk who did maintain an interest in the philosophy of religion - the field in which he gained his doctorate but whose interest at that time was shifting toward biomedical ethics. Van Niekerk took over as chair from 1990 and, with the help of Esterhuyse, in that same year created the Centre for Applied Ethics (initially with two units, viz. for biomedical and business ethics). Esterhuyse was from 1990 until his retirement in 1998 seconded to the University of Stellenbosch Business School where he taught business ethics to MBA and other students. The creation of this centre, in turn, gave rise to the implementation of a new and quite successful MPhil Program in Applied Ethics since 1996. This entire shift in strategic positioning in the Philosophy Department greatly facilitated the unification of the two departments in 1989.

The realisation increasingly grew that, whatever purpose the separated departments might have served in the past, the times had changed and that the rationale (if any) for the continuance of two departments no longer existed. It also became apparent that there was unnecessary overlap in the 
courses offered by both departments. Consequently, there was complete consensus amongst all members of staff, as well as in the ranks of the university management, that a unification of the two structures would be desirable.

The Kweekskool, in the sense of both the Theology Faculty and the Seminary for the training of Dutch Reformed clergy, was never officially consulted about the matter, and no objection from those quarters was ever raised. The unification of the departments occurred without any official comment from the Kweekskool. Because philosophy continued to be formally regarded as an important subject for clergy and theologians in training, the Philosophy Department was officially represented on the Faculty Board of the Theological Faculty from the early 1970's up to the first decade of the $21^{\text {st }}$ century. During this time, both Rossouw and Van Niekerk (who were the representatives) played prominent roles as chairpersons of committees that investigated new programs for theological training in that faculty.

The unification of the two departments occurred between the years 1986 and 1990. The initial steps to accomplish this were suggested by $\mathrm{Du}$ Toit in the early 1980's and thoroughly investigated by him and Esterhuyse, then chair of the Philosophy Department. Both played a pivotal role in the process. From 1986 to 1989 a model was construed in terms of which the offering of courses in the two subjects would be rationalised. Students could continue to take philosophy and political philosophy as subjects, but in the second and third years of study the full credit count for the subject of Political Philosophy could only be made up with choices of modules from other departments, viz Philosophy and Political Science. The first year module in logic was compulsory for all philosophy and political philosophy students, and was henceforth jointly offered by lecturers of both departments. Students were able to take both subjects simultaneously (although few ever chose to do so) and special arrangements were prescribed in order to prevent these students from having to follow the same modules for both subjects. ${ }^{10}$ It must be noted that Du Toit left for a new position at UCT from 1987. Van Niekerk acted as chair of the Philosophy Department during 1985 and 1986. Degenaar retired at the end of 1991.

10 See Yearbook(s) of Stellenbosch University, 1986: 75-177 \& 117-119; 1987: 71-72 \& 114117; 1988: 70-72 \& 114-117. At the time, the Yearbook was only available in Afrikaans. 
In 1989 Political Philosophy as a separate department with separately identified courses (albeit rationalised as just explained) officially ceased to exist. The 1989 Yearbook indicates only one department offering two courses or 'streams', viz. philosophy and political philosophy. The subject of political philosophy thus continued as a second stream (Afrikaans: 'baan') in the Philosophy Department. The first chair of the united department was Willie Esterhuyse. From 1990 to 2000, and again from 2006 to 2013, Van Niekerk, who became full professor in July 1989, chaired the department. Degenaar, who retired at the end of 1991, was not at all interested in managing the united department. The courses offered at each year level were all tabled in the Yearbook, and it was specified which courses students had to take in order to attain recognition that they followed either philosophy or political philosophy. ${ }^{11}$ This division continued until well into the 1990's. The question might be raised as to why the division of the two subjects was continued in view of the fact that the rationalisation of work was a strong motive for re-unification. The answer to this is that political philosophy, although always considerably smaller in numbers than philosophy, continued to draw mainly law students who also generally turned out to be rather good students - without, of course, implying that the philosophy students were not also smart! The fact of the matter was that timetables were so construed that it was de facto quite difficult for these law students to take philosophy as a subject; hence the need to continue political philosophy. That changed in the first decade of the $21^{\text {st }}$ century, with the result that, in that decade, all remnants of the earlier division disappeared.

Although the process of finally re-uniting the two departments therefore turned out to be protracted and lasted for the better part of half a decade, it occurred without any noticeable tensions between colleagues or students and, in the end, was welcomed by the rest of the university community. The Dutch Reformed Church which played such a pivotal role in the split of the 1960 's disappeared as a relevant participant in the process.

11 Yearbook of Stellenbosch University, 1989: 55-59. 


\section{Concluding remarks}

Time and space do not allow me any elaborate comments on the events narrated above. I would however, like to settle for three brief remarks.

1. Although this article dealt with a memorable event in the history of the department(s), faculty and university, it must be stated up front that these events were most unfortunate. Today it is unthinkable that a church, or individuals promoting a certain type of theology, could interfere in the academic affairs of a university in this way. Few values are as important to university culture and practice as academic freedom and institutional autonomy. Both were seriously violated with these events. It remains an unanswered question why senior and normally quite outspoken academics outside of the Department Philosophy at the time did not voice more urgent concerns about these matters, unless the process was so handled that the full story behind events was not adequately brought into the open. That these events were possible at Stellenbosch at this time in history, again shows the extent to which the university was viewed, and abused, as a 'volksuniversiteit', as the latter term was later on to be adopted by Prof. Thom in an infamous address in 1965 in which he explicitly argued that the core of academic freedom resides in obedience to the (apartheid) laws. He also strongly argued that Stellenbosch University ought to remain bound to the Afrikaner people ('volksgebonde') (Thom 1965). The events narrated in this article, cannot be interpreted outside of this context.

It is nevertheless interesting to note that, despite his criticisms of the volksuniversiteit, and views of people like Verwoerd, Thom and AP Treurnicht, Degenaar's own view of the nature of a university - incidentally a favourite topic which he for many years prescribed to his first year students - contains an ambivalence that sometimes creates the impression that he himself was not entirely unsympathetic to the idea of a Volksuniversiteit. André du Toit points to this ambivalence in his article about Socratic freedom and the volksuniversiteit in the Festschrift for Degenaar edited by Hertzog, Britz and Henderson (Du Toit 2006). Du Toit discusses a 1977 article of Degenaar (Degenaar 1977) in which he (Degenaar), on the one hand, analyses the notion of a volksuniversiteit in the very terms by which it is normally promoted by its adherents, and then in the process shows that the academic freedom of a volksuniversiteit, understood in the very 
terms propounded by its propagators, cannot be threatened by a true, critical, Socratic dialogue, as these proponents seem to fear. On the other hand, he, by implication, also takes a very critical stance of the notion of a volksuniversiteit because of its scepticism towards Socratic dialogue. Degenaar's view of the volksuniversiteit thus turns out to be considerably more complex than is usually thought.

2. The events surrounding Degenaar's teaching and the reaction it evoked, are indicative of the way in which a certain model of religious experience and faith that was quite prominent in DRC circles in the late $19^{\text {th }}$ century, was systematically overtaken by another model in the course of the early $20^{\text {th }}$ century. Both HW Rossouw (see his 2000) and Vincent Brümmer (see his 2013) refer to these developments, albeit it with different names. Rossouw calls it the replacement of a tolerant or irenic orthodoxy with a fundamentalist, antithetical orthodoxy. Brümmer typifies it as the tension between the emphasis on piety and the emphasis on obedience to doctrine ('regsinnigheid'). Alternatively, Brümmer identifies it as the tension between mystics and confessionalists. Rossouw and Brümmer both argue that $\mathrm{Du}$ Plessis (and I would add, Degenaar later on) were educated in a context of theological practice and faith experience in which Christian orthodoxy was not entirely relinquished, but where the primary emphasis fell on the individual experience of faith, and where the effects of Christian commitment on the lives of individual people were regarded as of much more importance than strict adherence to the doctrines espoused in the confessions of the church. In addition, it was also an approach in which the change that faith could bring to the world was much more observed and practised in the lives of individuals than in the transformation of the structures and institutions of society. Brümmer quotes GK Chesterton's analogy of the difference between these two models with reference to the mystic St Francis of Assisi: 'To this great mystic his religion was not a thing like a theory, but a thing like a love affair'! (Brümmer 2013:15). This mystic tradition, although now couched in an existential interpretation along the lines of Kierkegaard, does explain aspects of Degenaar's work in philosophy and theology in the 1950's and early 1960's. He was, in the process, a victim of the removal of the hold or influence that this tradition had on the DRC in the late $19^{\text {th }}$ century, e.g. in the work of Andrew Murray and Nicolaas Hofmeyr. The actions against Degenaar were driven by the 
adherents of the other grouping or tradition, i.e. the strict confessional tradition strongly influenced by Abraham Kuyper (i.e. people like Koot Vorster and FJM Potgieter) who, at the time, also gained supremacy in terms of leadership roles in the DRC. The most influential church leader in the Degenaar affair, however, was JS Gericke who, at the time, was also the Vice-Chancellor and Chairman of the Stellenbosch University Board as well as chairperson of the kuratorium. (The positions of vice-chancellor and rector of the university were, at that time, separated.) Gericke was by no means a Kuyperean; the mystic tradition seems to have also influenced him. However, he was hardly a theologian of any note; only a wielder of considerable ecclesiastical and political power.

What we have seen since the 1980's up to today, is a combination of the gradual return to the values of the mystical tradition, with increasing secularisation and a concomitant loss of interest in the issues surrounding Degenaar in the 1950's - developments that have greatly facilitated the healing of the breach in the Philosophy Department since 1987.

3. Finally, I would like to note the value of the maintenance of excellent personal relations and loyal collegiality in the face of crisis, as we saw in the reactions of Degenaar, Kirsten, Rossouw, Du Toit and Esterhuyse (as well as all other colleagues that followed) to the events narrated above. Kirsten and Degenaar, in particular, were in serious danger of mutual alienation and a fractured personal relationship because of these events. Yet, they never allowed that to occur, and continued a cordial and mutually respectful relationship right up to Kirsten's death in 1992. Had this not been the case, the situation in the two departments could easily have deteriorated into jealousy, acrimony and destructive competition, to the serious detriment of the future of philosophy as discipline at Stellenbosch University. A healthy culture of not only respect but also continued philosophical and political debate between all colleagues was maintained throughout the thirty years of separation, thus illustrating the value of dialogue over intellectual immobility. For that example we can all be thankful. ${ }^{12}$

12 I wish to sincerely thank Hennie Rossouw, Willie Esterhuyse, Vincent Brümmer, Etienne Britz, Jacques Kriel and André du Toit for their valuable comments on the original manuscript. I also wish to thank the personnel of both the Stellenbosch University and the Dutch Reformed Church Archives at Stellenbosch for their valued assistance. I am responsible for all remaining faults. 


\section{References}

Anthonissen, C Undated. Die onwaarskynlike hervormer: impulse van Johan Degenaar se lewe en denke tot geloofvernuwing. Stellenbosch: Unpublished.

Brümmer, V 2013. Vroom of regsinnig? Teologie in die NG Kerk.

Wellington: Bybel-Media.

Degenaar, JJ 1963. Die sterflikheid van die siel. Johannesburg: Simondium Uitgewers.

Degenaar, JJ 1977. The concept of a 'Volkuniversiteit'. In: HW van der Merwe \& D Welsh (eds.) The Future of the University in South Africa. Cape Town: David Philip: 148-171.

Du Toit, AB 1986. In gesprek: Opstelle vir Johan Degenaar. Cape Town: Die Suid-Afrikaan.

Du Toit, AB 2006. Sokratiese Vryheid aan 'n volksuniversiteit. In: D Hertzog, E Britz \& A Henderson, Gesprek sonder Gense. Stellenbosch: H\&B Uitgewqers, 2006: 94-111.

Du Toit, AB 2015. Johan Degenaar - ter herinnering. Speech at memorial event for Johan Degenaar, 1 August 2015. [Intyds]. Beskikbaar: http:// www.litnet.co.za/johan-degenaar-ter-herinnering/

Hertzog, D, Britz, E \& Henderson, A 2006. Gesprek sonder Grense: Huldigingsbundel ter ere van Johan Degenaar se $80^{\text {ste }}$ verjaardag. Stellenbosch: H\&B Uitgewers.

Kirsten, JF 1962. Aansoek: Senior Lektoraat, Departement van Filosofie (Unpublished motivation for creation of senior lectureship in SU Philosophy Department from 1 January 1963, SU Archives).

Kirsten, JF 1972. Brümmer, Nicolaas Johannes. South African Biographical Dictionary, vol. 2: 95-96.

Kriel, J 2016. Brief aan Anton van Niekerk, 16 August 2016. (Unpublished). Malan, D 1954. Ons idee van die siel en waar dit vandaan kom. Polumnia: 36-39. 
Nash, A 1997. How Kierkegaard came to Stellenbosch: the transformation of the Stellenbosch philosophical tradition: 1947-1950. SA Journal of Philosophy, 16 (4): 129-139.

Nash, A 2009. The dialectical tradition in South Africa. New York: Routledge.

Rossouw, HW 1973. By die aftrede van prof. JF Kirsten. Ned Geref Teologiese Tydskrif, 15 (4), September 1973: 235-236.

Rossouw, HW 2000. Die Du Plessis-saak. Unpublished lecture, originally delivered to Degenaar discussion group, 3 November 2000.

Thom, HB 1958a. Handwritten notes of meeting with GP van der Berg, JD Vorster, JS Gericke, JF Kirsten \& JJ Degenaar (SU Archives).

Thom, HB 1958b. Letter, dated 8 July 1958, to dr JD Vorster (SU Archives)

Thom, HB 1965. Universiteit en maatskappy. Elsiesrivier: Nasionale Handelsdrukkery. [Intyds] Beskikbaar: https://igital.lib.sun.ac.za/bitstream/ handle/10019.2/3812/thom-191-t-7-49.pdf?sequence $=1$

Thom, HB (red). 1966. Stellenbosch 1866-1966: Honderd jaar van hoër onderwys. Kaapstad: Nasionale Boekhandel.

Yearbooks of Stellenbosch University, Stellenbosch: Stellenbosch University, 1986-1991.

Vorster, JD 1958. Letter, dated 10 July 1958, to HB Thom (SU Archives).

\section{Interviews and minutes}

Interview with HW Rossouw, 11 May 2016

Interview with $\mathrm{AB}$ du Toit, 30 June 2016

Kriel, J. Letter to author (unpublished), 2016.

Minutes of Stellenbosch University Faculty Board for Arts and Philosophy:

- 7 May 1958

- 11 October 1958

- 9 October 1966 